\title{
Groundwater surface mapping informs sources of catchment baseflow
}

\author{
J. F. Costelloe ${ }^{1}$, T. J. Peterson ${ }^{1}$, K. Halbert ${ }^{2}$, A. W. Western ${ }^{1}$, and J. J. McDonnell ${ }^{3,4}$ \\ ${ }^{1}$ Department of Infrastructure Engineering, University of Melbourne, Melbourne, Australia \\ ${ }^{2}$ Ecole Centrale de Nantes, Nantes, France \\ ${ }^{3}$ Global Institute For Water Security, University of Saskatchewan, Saskatoon, Canada \\ ${ }^{4}$ School of Geosciences, University of Aberdeen, Aberdeen, Scotland
}

Correspondence to: J. F. Costelloe (jcost@unimelb.edu.au)

Received: 13 October 2014 - Published in Hydrol. Earth Syst. Sci. Discuss.: 5 November 2014 Revised: 9 March 2015 - Accepted: 9 March 2015 - Published: 7 April 2015

\begin{abstract}
Groundwater discharge is a major contributor to stream baseflow. Quantifying this flux is difficult, despite its considerable importance to water resource management and evaluation of the effects of groundwater extraction on streamflow. It is important to be able to differentiate between contributions to streamflow from regional groundwater discharge (more susceptible to groundwater extraction) compared to interflow processes (arguably less susceptible to groundwater extraction). Here we explore the use of groundwater surface mapping as an independent data set to constrain estimates of groundwater discharge to streamflow using traditional digital filter and tracer techniques. We developed groundwater surfaces from 88 monitoring bores using Kriging with external drift and for a subset of 33 bores with shallow screen depths. Baseflow estimates at the catchment outlet were made using the Eckhardt digital filter approach and tracer data mixing analysis using major ion signatures. Our groundwater mapping approach yielded two measures (percentage area intersecting the land surface and monthly change in saturated volume) that indicated that digital filter-derived baseflow significantly exceeded probable groundwater discharge during most months. Tracer analysis was not able to resolve contributions from ungauged tributary flows (sourced from either shallow flow paths, i.e. interflow and perched aquifer discharge, or regional groundwater discharge) and regional groundwater. Groundwater mapping was able to identify ungauged sub-catchments where regional groundwater discharge was too deep to contribute to tributary flow and thus where shallow flow paths dominated the tributary flow. Our results suggest that kriged groundwa-
\end{abstract}

ter surfaces provide a useful, empirical and independent data set for investigating sources of fluxes contributing to baseflow and identifying periods where baseflow analysis may overestimate groundwater discharge to streamflow.

\section{Introduction}

Groundwater discharge is a major contributor to stream baseflow. Quantifying this flux is of considerable importance to water resource management (Woessner, 2000; Sophocleous, 2002; Cartwright et al., 2014). In recent decades there have been dramatic increases in the extraction of groundwater for agricultural use, driven by factors such as expansion of irrigated agriculture in southern Asia (Llamas and MartínezSantos, 2005; Perrin et al., 2011) and long-term drought in southeastern Australia (Leblanc et al., 2012; van Dijk et al., 2013). It has been long recognised that over-extraction from aquifers may result in significant long-term declines in groundwater levels, resulting in decreases in baseflow in rivers (Bredehoeft et al., 1982). As a result, the switch to groundwater as a source of irrigation supply has the potential to exacerbate decreases in baseflow in rivers already experiencing reductions in flow from drought or instream water use. Whilst these generalities of groundwater extraction and stream baseflow reduction are clear, the particularities for any given catchment are complex and difficult to quantify. The separation of baseflow contributions from regional groundwater (i.e. where aquifers are unconfined in the vicinity of streams) from other shallower sources, like interflow, 
bank storage return and perched aquifer discharge, is technically difficult to quantify. Nevertheless, this is fundamentally important for quantifying how regional groundwater extraction may affect baseflow in rivers (Wittenberg, 1999). Despite decades of work (e.g. Nathan and McMahon, 1990; Tallaksen, 1995; Wittenberg, 1999; Eckhardt, 2005), methods to quantify and discriminate between "slow flow" (itself a poorly defined term) contributions to the stream using only streamflow data are approximate at best.

From a physical perspective, the baseflow component of streamflow is the sum of the slow flow pathways into the river (Ward and Robinson, 2000). Regional, unconfined groundwater (often termed "deep groundwater") can discharge into the river via the valley floor or through more shallow, lateral flow paths, such as discharge into tributaries draining the valley slopes. Rain event driven interflow pathways can also contribute to tributary streamflow and recent work has shown a continuum between groundwater and interflow processes (sometimes referred to as "shallow groundwater" in hilly terrains) along the stream reach (Jencso et al., 2009; Jencso and McGlynn, 2011). In terms of water resource extraction (e.g. for urban supplies or irrigation on the valley floor), groundwater pumping typically targets the deep groundwater, and often in alluvial valley locations where the depth to groundwater is at a minimum. Thus, it is important to be able to differentiate between contributions to streamflow from deep groundwater discharge (more susceptible to groundwater extraction) compared to shallower interflow processes (arguably less susceptible to groundwater extraction).

But how can the baseflow components be identified? Digital recursive filters are the most common method of separating baseflow from streamflow but do not discriminate between the different components of baseflow, and the estimate is integrated over the entire catchment area upstream of the gauging station. The technique rests on the assumption that baseflow is comprised of linear or non-linear outflow from an aquifer (e.g. Nathan and McMahon, 1990; Wittenberg, 1999; Eckhardt, 2005). All of the filter approaches require calibration of 1-3 parameters based on subjective criteria (e.g. recession curve analysis, typical values, etc.). Calibration of these parameters against synthetic baseflow derived from a numerical model has shown that optimal values vary considerably with catchment and climatic characteristics, many of which are not known or not possible to know a priori for natural catchments (Li et al., 2014).

There is typically significant variability in recession curves from a given catchment, suggesting a range of processes, stores and flow paths (e.g. deep and shallow groundwater flow paths, interflow, bank storage) affecting baseflow (Tallaksen, 1995; Jencso and McGlynn, 2011; Chen and Wang, 2013). The regional unconfined groundwater may drive only some of this response (Cartwright et al., 2014) and the baseflow derived from unconfined groundwater is commonly defined by the slowest recession flows that form the lower bound (e.g. the 95th percentile) of all recession curves used in the analysis (Brutsaert, 2008; Eckhardt, 2008). The variable, often non-linear, baseflow response has been attributed to additional processes affecting the groundwater discharge, such as phreatic evapotranspiration (Wittenberg and Sivapalan, 1999) and recharge from soils or perched aquifers (Fenicia et al., 2006; Jencso and McGlynn, 2011). Baseflow analysis using digital recursive filters typically does not use groundwater data to constrain or test the estimates, even though baseflow should vary systematically with groundwater levels (Gonzalez et al., 2009; Meshgi et al., 2014).

Tracer data are also commonly used to estimate groundwater discharge to streams (Cook et al., 2003; McGlynn and McDonnell, 2003; Cartwright et al., 2011; Atkinson et al., 2015). The tracer approach relies on the assumption that different contributors to streamflow have distinctive and invariant chemical, isotopic or radiogenic end-member signatures that can be apportioned in the streamflow mixture (McCallum et al., 2010). From a geochemical perspective, mass balance estimates of baseflow using tracer data can differ from estimates made by digital recursive filters, as some slow flow components (e.g. bank storage) can be geochemically similar to quick flow components (Cartwright et al., 2014). Insights have been gained into heavily instrumented catchments that increase confidence in the identification of sources and pathways of the fluxes to the stream - but this is usually feasible only on small experimental catchments or hillslopes (Kendall et al., 2001). In larger catchments utilised for water use, it can be difficult to separate fluxes of interest due to similarities in the tracer signatures, such as between surface flow and interflow (Kendall et al., 2001) or bank storage discharge and streamflow (McCallum et al., 2010). This problem has been addressed by using a multiple tracer approach, so that a mix of isotopic and ionic data or conservative and radiogenic data can provide independent information on sources and pathways within a catchment (Cook et al., 2003; Cartwright et al., 2011; Atkinson et al., 2015). However, field studies are rarely able to identify end-members for all flow paths of interest, and deep and shallow groundwater fluxes are commonly lumped together.

Digital recursive filters and tracer-based analysis measure different components of baseflow and provide different bounds to the estimation of groundwater discharge. For instance, digital filter analysis provides an upper bound to groundwater discharge, integrated over the upstream catchment area. Tracer analysis can provide more spatially explicit estimates of groundwater discharge, but can struggle with separating discharge from deep groundwater flow paths compared to shallow, lateral groundwater flow paths. Here we argue that additional data sets on groundwater dynamics are of benefit in better constraining regional groundwater discharge estimates determined by these traditional methods. One overlooked measure available in many catchments is groundwater level data. Intuitively, such data are directly relatable to the groundwater discharge component of baseflow (Gonzalez et al., 2009; Meshgi et al., 2014). More importantly, we 
hypothesise that groundwater observations provide complementary, independent time series of data on the dynamics of the groundwater-surface water interaction.

The use of groundwater level data at the reach or catchment scale faces a number of challenges, principally that these data are sporadically available in time and space. To understand the spatial variability of groundwater throughout a catchment, various geostatistical techniques have been developed to interpolate sparse groundwater level observations (Desbarats et al., 2002; Boezio et al., 2006; Lyon et al., 2006). However, to date, maps have been derived for only the average groundwater level at each bore, rather than distributed instantaneous levels across the catchment (Desbarats et al., 2002), or at a specific time using either continuous water level observations (Boezio et al., 2006; Lyon et al., 2006) or basic hydrograph interpolation methods (Peterson et al., 2011) that ignore the variability between observation times. Considering that groundwater observations are most often collected manually and are rarely coincident across a catchment, using groundwater maps to inform groundwatersurface water interaction requires maps for specific time points and hence a hydrograph interpolation technique that, ideally, accounts for the variability between observations. Recently, Peterson and Western (2014) developed such an interpolation approach for irregularly spaced observations that now allows for daily interpolated observations to be generated for the estimation of groundwater surfaces for any given date within the period of observation. This new method enables the generation of high-frequency groundwater surfaces from operational monitoring bore networks, which opens up a possible new way forward for estimating groundwater contributions to baseflow.

Here we combine groundwater head data, amalgamated as groundwater surface maps using the new Peterson and Western (2014) temporal interpolation with the Peterson et al. (2011) spatial interpolation approach. We then use this as an independent and generally available approach to constrain estimates of groundwater discharge to streamflow using traditional digital filter and tracer techniques. Specifically we test three hypotheses:

1. variations in baseflow can be explained by variations in the areas of very shallow water tables (i.e. direct discharge areas),

2. variations in baseflow can be explained by changes in saturated volume between monthly water table surfaces, and

3. water table mapping can identify whether ungauged tributary inflow is driven by regional groundwater discharge.

We focus our work on a humid catchment in southeastern Australia where substantial groundwater data have been collected arising from investigations of groundwater extraction

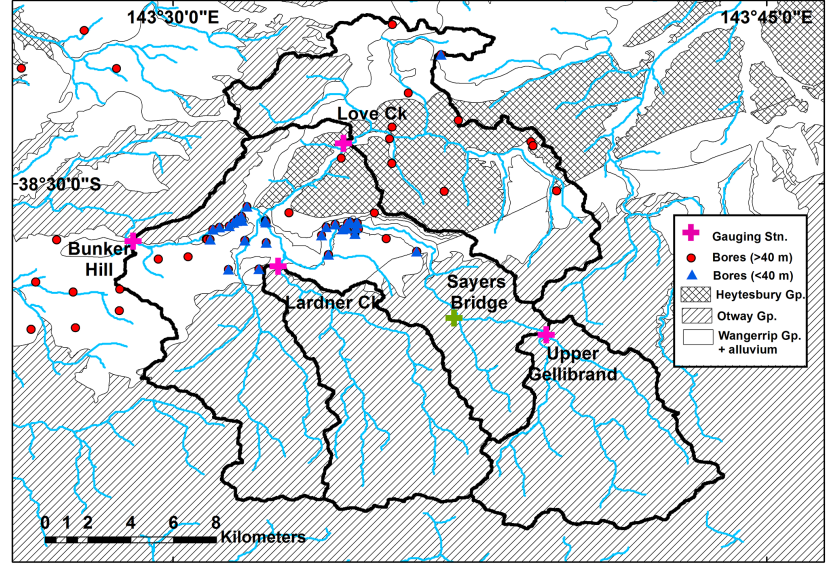

Figure 1. Location and geology of the Gellibrand River catchment in Victoria, Australia, showing catchment and gauged subcatchment boundaries, monitoring bores, gauging stations and the Sayers Bridge (ungauged) river sampling location.

for urban water supply (SKM, 2012) and river damming. We combine 44 years of streamflow and groundwater data observations from 88 monitoring bores across the $311 \mathrm{~km}^{2}$ catchment to investigate the utility of the groundwater data for informing sources of catchment baseflow.

\section{Methods}

\subsection{Study area}

The Gellibrand River catchment is located in southeastern Australia in the Otway Ranges. It has a perennial, highly seasonal flow regime and a humid climate (rainfall of $1000 \mathrm{~mm} \mathrm{a}^{-1}$ ). The Gellibrand River is dominated by a constrained valley with much of the study reach being forested by cool temperate eucalypt rainforests, except for cleared grazing areas along the valley floor. The catchment is well gauged, with gauging stations at Upper Gellibrand and Bunker Hill on the Gellibrand River and gauging stations measuring flow in two of the larger tributaries (Love Creek and Lardner Creek, Fig. 1). The catchment has an area of $311 \mathrm{~km}^{2}$ to a mid-catchment gauging station at Bunker Hill. Comparison of potentiometric groundwater data to river levels indicates mostly gaining conditions along the Gellibrand River (SKM, 2012; Atkinson et al., 2015).

The southern half of the catchment, which includes the upper reaches of the Gellibrand River and coincides with steep, forested terrain, is underlain by the volcanogenic sandstones, siltstones and mudstones of the Cretaceous Otways Group (Fig. 1), which forms the basement to the catchment. Relatively few bores occur within this unit in the Gellibrand catchment. The more open, alluvial valley of the Gellibrand is underlain predominantly by fluvial sands with interbedded silts and clays of the late Cretaceous Wangerrip 
Group and overlying Quaternary alluvium. This area contains the most bores and is considered the primary aquifer in the region (Atkinson et al., 2015). The northern half of the catchment, particularly the Love Creek sub-catchment, is underlain by the marine calcareous clays of the Miocene Heytesbury Group that confine the underlying aquifers in the Wangerrip Group. A number of bores occur in this area, but are mainly screened within the main aquifer (Eastern View Formation) of the underlying Wangerrip Group.

\subsection{Groundwater monitoring and mapping}

Eighty-eight groundwater monitoring bores in and around the boundary of the Gellibrand catchment were identified and water level data were extracted from the Victorian Groundwater Management System (http://www.vvg.org.au/ cb_pages/gms.php). The area contains a relatively large number of monitoring bores due to earlier investigations for a potential damming of the Gellibrand River and also extraction of groundwater for urban water supply (SKM, 2012). Groundwater surfaces were constructed from the total data set and also from a subset of 33 bores with screened depths of $<40$ m that only occur within the catchment boundary (bore details in Supplement B). The total data set contains bores that are screened at greater depths in the Wangerrip Group (main aquifer) and these typically show higher heads relative to nearby bores screened at shallower depths (typically in the Quaternary alluvium). Groundwater surfaces from the total data set represent more of a potentiometric surface, while the smaller data set of shallow bores represents a water table surface.

In order to construct groundwater surface maps for specified dates, the periodic (generally monthly) water level observations of the bore data were first modelled using the nonlinear transfer-function-noise time series modelling methodology of Peterson and Western (2014). Water level estimates for the start of each month were then derived by adding the time series simulation, interpolated to the required data, to a univariate ordinary Kriging estimate of the time-series model error at the required date, which ensured a zero error at dates with a water level observation. Groundwater surface maps were then produced for the first of each month for the years 2007 to 2010 using the Kriging with external drift (KED) method (Peterson et al., 2011). In applying the KED, the external drift term was the land surface elevation (Shuttle Radar Terrain Model (SRTM) $30 \mathrm{~m}$ data set). A model variogram was derived for the component of the groundwater elevation not explained by the external drift. The KED approach requires the estimation of three parameters for the residual model variogram and a parameter for the maximum search radius during the mapping. Considerable effort was taken to reliably calibrate the variogram parameters and set a search radius producing cross-validation residuals that are approximately first-order stationary. The Kriging variance (see example in Fig. 6) does provides an indicative estimate of the map reliability for the given parameter set and the available water level observations. However, the density and location of observations also influences the variogram parameters and the maximum search radius parameter. Accounting for this parameter uncertainty in the groundwater mapping is not trivial and future work is required to explore methods that account for variogram uncertainty (Ortiz and Deutsch, 2002) and localised estimation of the search radius (Abedini et al., 2012). This groundwater level component was first estimated using ordinary least squares regression and then minimised by repeatedly fitting an isotropic exponential variogram, using multi-start Levenberg-Marquardt optimisation and re-derivation of the water level component, until a stable model variogram was achieved. The depth to groundwater was calculated by difference from the SRTM representation of the ground surface and used to measure changes in the percentage of the catchment with very shallow groundwater surfaces (nominally "saturated" within the uncertainty range of the groundwater surface position) over the period of mapping. This was done for the parts of the catchment with an elevation of $<100 \mathrm{~m}$ in order to analyse changes in the saturated area around the valley floor and lower slopes of the catchment where most monitoring bores were located and, hence, confidence in the groundwater surface mapping was highest. Three threshold depths to the water table $(0,0.5$, $1.0 \mathrm{~m}$ ) were used to determine changes between the seasonal maximum (spring) and minimum (autumn) saturated areas. The threshold depths were not calibrated, but were arbitrarily chosen to capture some of the uncertainty in the groundwater position (i.e. see Fig. 5 for an indication of the standard deviation in the groundwater surface positions) as mapped for each month. In addition, changes in total volume below the mapped groundwater surface (i.e. volume containing sediments and pore spaces) between months were calculated using the groundwater surface maps, again using the catchment area below $100 \mathrm{~m}$ elevation.

\subsection{Digital recursive filter analysis of baseflow}

The Eckhardt (2005) two-parameter, digital recursive filter (1) was used to produce baseflow time series for the Gellibrand streamflow record at the Bunker Hill gauging station (station number 235227):

$b_{k}=\frac{\left(1-\mathrm{BFI}_{\max }\right) a b_{k-1}+(1-a) \mathrm{BFI}_{\max } Q_{k}}{1-a \mathrm{BFI}_{\max }}$,

where $b\left(\mathrm{~L}^{3} \mathrm{~T}^{-1}\right)$ is the baseflow discharge, $Q\left(\mathrm{~L}^{3} \mathrm{~T}^{-1}\right)$ is the total streamflow discharge, $k(\mathrm{~T})$ is the time step, and $a(-)$ and $\mathrm{BFI}_{\max }(-)$ are parameters requiring calibration. The Eckhardt filter separates the slow flow component of the stream hydrograph based on the groundwater discharge being linearly proportional to the unconfined aquifer storage. This filter was chosen as it has a physical basis and produces results comparable with other digital recursive filters (Eckhardt, 2008). The $a$ parameter (representing the re- 
cession constant of streamflow) was determined by the 95 th percentile upper bound of the scatter plot of daily discharge $\left(Q_{k}\right)$ against discharge from the next day $\left(Q_{k+1}\right)$. These data points were extracted for recession flows of 5 days or longer (see Eckhardt, 2008) below a selection of percentiles of total flows (i.e. 30th, 40th, 50th). The $\mathrm{BFI}_{\max }$ parameter (representing the maximum value of the baseflow index, i.e. baseflow/total streamflow, that can be modelled by the filter algorithm) was chosen to minimise periods of baseflow greater than observed streamflow. The filter is typically applied with the condition that $b_{k} \leq Q_{k}$ (Eckhardt, 2005), but this is an arbitrary constraint, and we explore the resulting baseflow time series without this condition, except where stated. Time series of baseflow were then defined using the selected pairs of parameter values to represent a possible envelope of baseflow for the study catchment.

\subsection{Hydrochemical sampling and analysis}

Water samples from streamflow were collected by automatic samplers (ISCO) at several locations in the catchment, including upstream (Upper Gellibrand gauging station and Sayers Bridge, see Fig. 1) and downstream (Bunker Hill gauging station) locations from the Gellibrand River and from major tributaries in January and June 2013. Grab samples were also collected from smaller, ungauged tributaries and from the Gellibrand River during the sampling period and also in December 2013. Unconfined groundwater samples were taken from bores in the alluvial area of the Gellibrand River (some data supplied by Alex Atkinson, Monash University, see Atkinson et al., 2015) after purging 2-3 well volumes of bores or until field water parameters (e.g. electrical conductivity, $\mathrm{pH}$, temperature) had stabilised. Samples were filtered through a $0.45 \mu \mathrm{m}$ membrane filter and the cation aliquots were further acidified to $\mathrm{pH}<2$ using $1 \mathrm{M} \mathrm{HNO}_{3}$ and stored at $4{ }^{\circ} \mathrm{C}$ until analysis at the Research School of Earth Science laboratory, Australian National University. Cation analyses were performed by ICP mass spectrometry (Varian Vista AX CCD simultaneous ICP-OES) and anion analysis performed by ion chromotography (Dionex Series 4500i). Colourimetric alkalinity titrations were performed using a $\mathrm{Hach}^{\circledR}$ field titration kit.

Mass balance calculations were conducted on the streamflow samples using selected ions $(\mathrm{Cl}, \mathrm{Na}, \mathrm{Ca}, \mathrm{Mg})$ in a multiple end-member model. The hydrochemical samples included upstream and downstream (gauged) locations on the Gellibrand River, major gauged tributaries and a range of smaller, ungauged tributaries. The mass balance for a gaining reach is defined by the load (2) and the discharge (3):

$Q_{\mathrm{ds}} C_{\mathrm{ds}}=Q_{\mathrm{us}} C_{\mathrm{us}}+Q_{\mathrm{gw}} C_{\mathrm{gw}}+Q_{\mathrm{ut}} C_{\mathrm{ut}}+Q_{\mathrm{gt}} C_{\mathrm{gt}}$,

$Q_{\mathrm{ds}}=Q_{\mathrm{us}}+Q_{\mathrm{gw}}+Q_{\mathrm{ut}}+Q_{\mathrm{gt}}$,

where $Q$ is discharge and $C$ is concentration, and the subscripts refer to ds - downstream Gellibrand (Bunker Hill gauging station), us - upstream Gellibrand, gw - groundwater, ut - ungauged tributaries, and gt - gauged tributaries. The unknowns in the above equations are $Q_{\mathrm{gw}}$ and $Q_{\mathrm{ut}}$, and to solve them requires two sets of concentrations, or a single tracer with data over 2 or more days. This approach accounts for the contribution from the alluvial groundwater in the reach between the Upper Gellibrand and Bunker Hill gauging stations. To explore the uncertainty in the mass balance estimates, the composition of the groundwater end-member was varied by \pm 1 standard deviation, as this end-member had the largest standard deviation for two of the ions $(\mathrm{Cl}$ and $\mathrm{Na}$; see Supplement A) used in the calculations.

\section{Results}

We first analyse the baseflow characteristics of the river using the Eckhardt (2005) baseflow filter. Second, the streamflow chemical patterns are presented and third, mass balance analysis is used to estimate groundwater discharge and ungauged tributary discharge. Finally, using the results of mapping the groundwater surfaces, we analyse relationships between the three data sets (groundwater surfaces, baseflow filter estimates, mass balance tracer estimates) and explore how the groundwater surfaces can be used to constrain estimates of groundwater discharge derived from ionic mass balance and baseflow filter analyses.

\subsection{Baseflow analysis}

The Eckhardt baseflow estimates produce patterns that follow the highly seasonal pattern shown by the overall river discharge and indicated that baseflow significantly contributed to overall streamflow (Fig. 2). The $a$ parameter values declined moderately as the threshold flow percentile value to define recession periods increased (30th -0.990 , 40th $-0.988,50$ th -0.985$)$. The $\mathrm{BFI}_{\max }$ parameter values that minimised periods of baseflow greater than streamflow clustered around 0.2 but showed slight increases as $a$ decreased (30th $-0.20,40$ th $-0.20,50$ th -0.22 ). The resulting baseflow time series using these parameter values were similar and the time series using $a=0.988$ and $\mathrm{BFI}_{\max }=0.20$ is shown in Fig. 2. This method used for determining the $\mathrm{BFI}_{\max }$ parameter produced values below the recommended range $(\sim 0.8$ for perennial rivers with porous aquifers, Eckhardt, 2005) and that lie closest to the recommended $\mathrm{BFI}_{\max }$ value $(0.25)$ for perennial rivers with hard rock aquifers. In Fig. 2 we also show baseflow time series using $a=0.988$ and the recommended $\mathrm{BFI}_{\max }$ value for a river such as the Gellibrand (0.80), and also using the maximum baseflow index value (0.60) found for the Gellibrand River using tracerbased analysis by Atkinson et al. (2015). Using the condition of $b_{k} \leq Q_{k}$, the filtered baseflow time series produced mean monthly BFI estimates of $0.48-0.55\left(\mathrm{BFI}_{\max }=0.20-0.22\right)$ and $0.63-0.68\left(\mathrm{BFI}_{\max }=0.60-0.80\right)$ during the summer- 

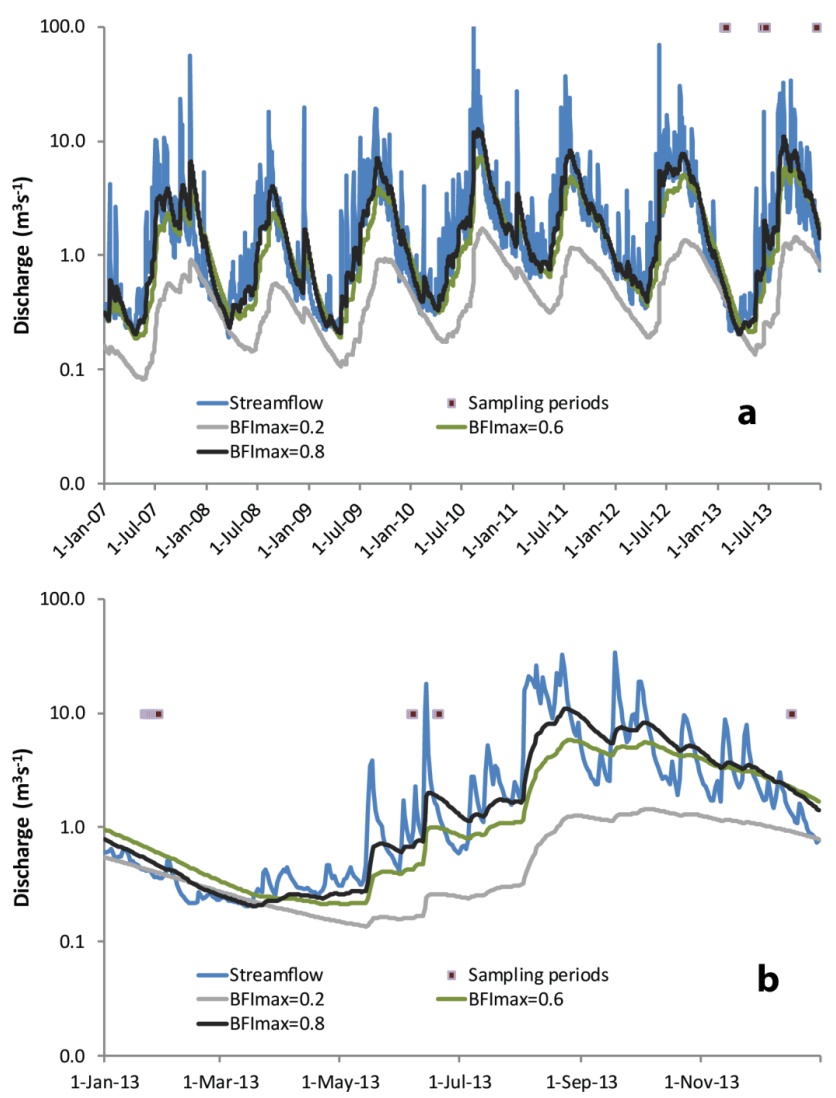

Figure 2. Hydrograph at Bunker Hill gauging station (235227) illustrating the seasonality of flow. Three baseflow separation hydrographs generated using different $\mathrm{BFI}_{\max }$ parameter values $(0.20$, $0.60,0.80$ and $a=0.988$ ) for the Eckhardt filter are displayed, along with the periods of hydrochemical sampling of streamflow during 2013.

autumn period (December-May), and 0.21-0.24 $\left(\mathrm{BFI}_{\max }=\right.$ $0.20-0.22)$ and $0.47-0.58\left(\mathrm{BFI}_{\max }=0.60-0.80\right)$ during the winter-spring period (June-November).

\subsection{Streamflow chemistry patterns}

Streamflow and groundwater samples of the Gellibrand catchment have similar $\mathrm{Na}-\mathrm{Cl}-\mathrm{HCO}_{3}$ compositions (Supplement A) and are further examined using a Piper diagram (Fig. 3). The upstream, downstream and major tributary flow compositions plot closely together, with the downstream composition showing a shift towards the alluvial groundwater composition, relative to the upstream composition. However, seasonal changes in streamflow chemistry are also apparent, with winter samples (June 2013) plotting closer to the groundwater composition (higher $\mathrm{Cl}$, lower $\mathrm{HCO}_{3}$ ) in comparison to the summer low flow samples (January and December 2013). The ungauged (minor) tributary samples show a greater spread in compositions, with only the largest of the ungauged tributaries (Charley's Creek, $47.4 \mathrm{~km}^{2}$ ) plotting with the gauged streamflow (Gellibrand, Love, Lard-
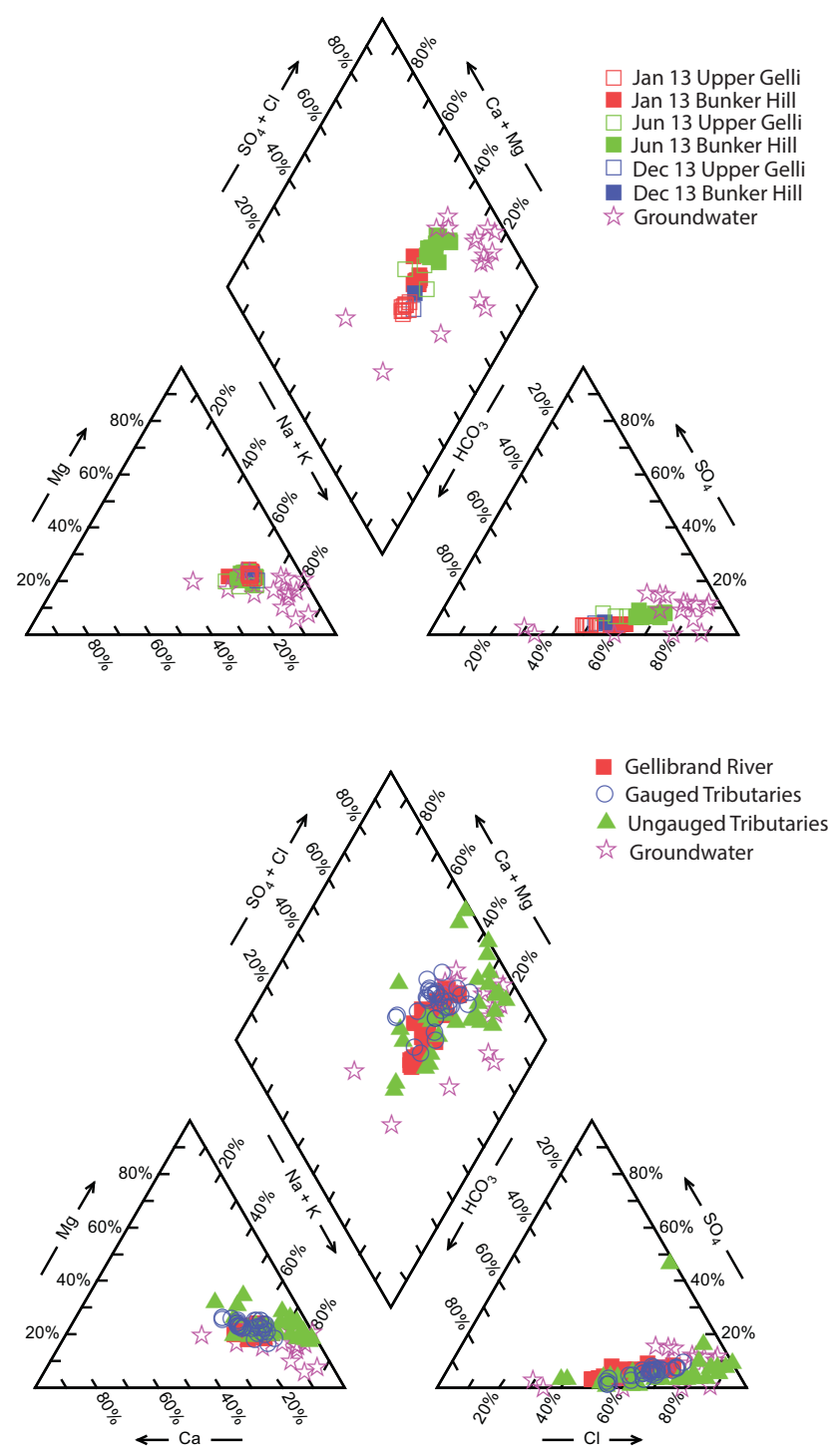

Figure 3. Piper diagrams showing temporal and spatial patterns in the chemistry of streamflow and groundwater. The top panel shows seasonal variations in the composition of flow in the Gellibrand River at the upstream (Upper Gellibrand) and downstream (Bunker Hill) sites over three sampling trips. The data in the upper plot show compositional change from upstream to downstream and also from summer to winter towards the general groundwater composition. The lower panel shows compositional differences across all sampling trips between the Gellibrand River, gauged tributaries, ungauged tributaries and groundwater.

ner), and others plotting in and around the alluvial groundwater compositions. The Charley's Creek subcatchment drains the southern half of the catchment underlain by the Otways group and has a relatively similar area to the two gauged tributaries (Lardner Creek $51.8 \mathrm{~km}^{2}$, Love Creek $76.6 \mathrm{~km}^{2}$ ). The ungauged tributaries show a greater spread in composition than the alluvial groundwater, but this was dominated by relatively high $\mathrm{Mg}$ and $\mathrm{SO}_{4}$ concentrations in two tributaries, 


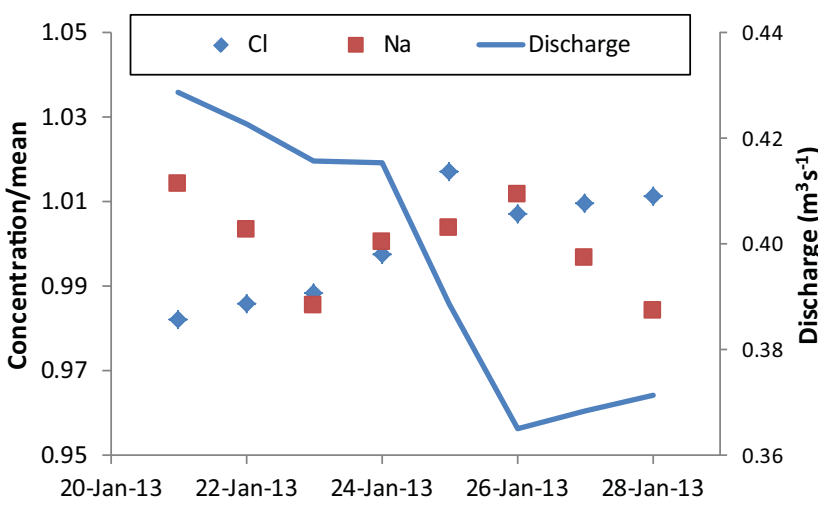

Figure 4. Major ion changes during streamflow recession of January 2013 measured at Bunker Hill gauging station. Concentrations are divided by the mean concentration of the sampling period for each tracer.

whilst the other tributaries were slightly depleted in $\mathrm{Ca}$ and $\mathrm{K}$ compared to the alluvial groundwater. The Love Creek samples have significantly higher ionic concentrations than all other streamflow samples in the catchment (Supplement A), but have similar ionic ratios, as shown by them plotting closely to the gauged streamflow samples in Fig. 3.

The dominance of the contribution of groundwater discharge to streamflow during summer low flow periods was also investigated by examining how tracer values changed during the recession of flow events during the summer (January 2013) sampling period (Fig. 4). In general, only the chloride data showed an approximately linear increase in concentration that would be expected if the groundwater discharge flux contributed proportionally more to streamflow during the short-term recession. The other major ions (e.g. $\mathrm{Na}, \mathrm{Ca}, \mathrm{Mg}$ ) remained relatively consistent or showed a variable pattern over time during the flow recession. In addition, the streamflow composition remains distinct from the groundwater composition even during the summer low flow periods (Figs. 3, 4). These patterns suggest that other endmember fluxes need to be considered during the flow recession rather than a simple two end-member system (i.e. upstream streamflow and groundwater discharge).

The compositional similarities of the ungauged streamflow samples to the alluvial groundwater samples, compared to the gauged streamflow samples, raise the question of whether the minor ungauged tributaries represent discharged groundwater. Alternatively, the ungauged streamflow may be driven by perched aquifer or similar interflow-type processes. If the ungauged tributary samples represent a source distinct from the regional groundwater, then their chemical similarity to the groundwater samples could result in chemical mass balance techniques that do not consider the contribution from ungauged tributaries, overestimating the groundwater contribution to streamflow (Sect. 3.3).
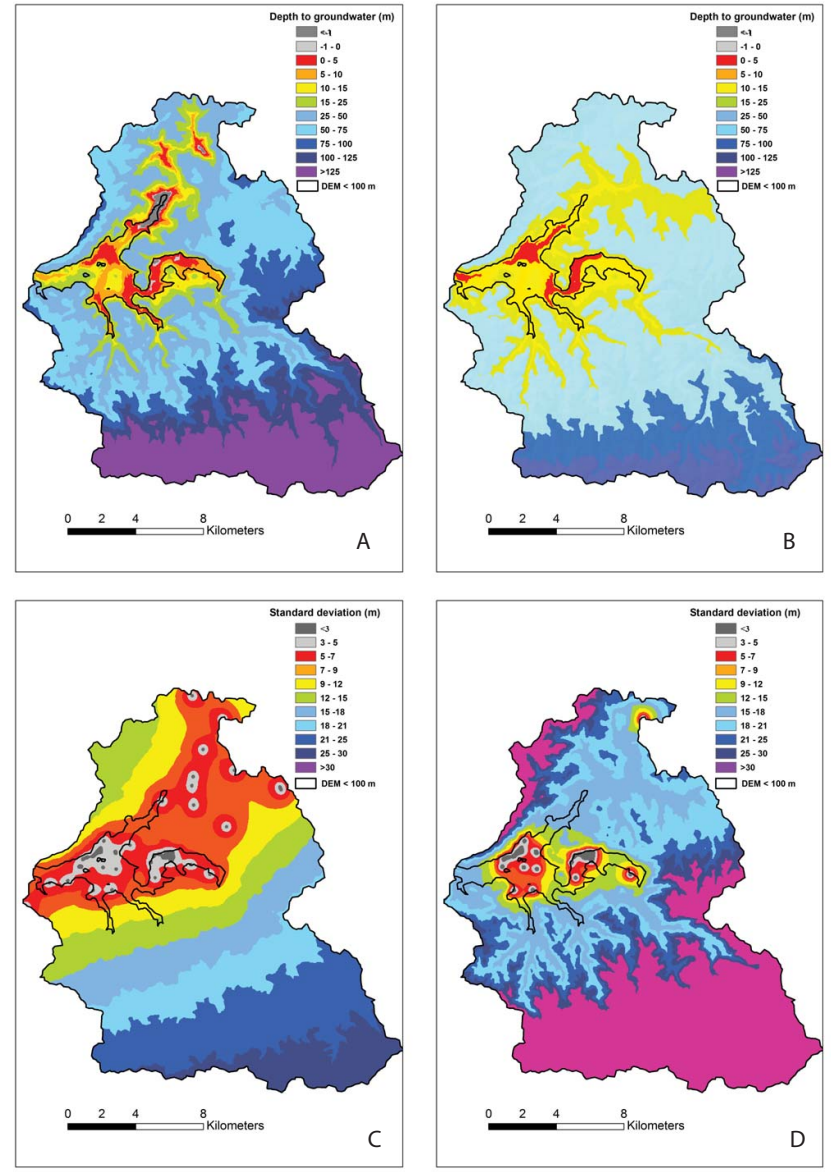

Figure 5. Depth to groundwater maps (a - "potentiometric surface" (all bores), b - "water table" (shallow bores)) and Kriging standard deviation (c-potentiometric surface, $\mathbf{d}$ - water table) for 1 September 2009. Areas of shallow or intersecting (artesian) groundwater are restricted to the Gellibrand River (centre) and Love Creek (north) valley floors.

\subsection{Mass balance analysis}

Mass balances were calculated using $\mathrm{Cl}, \mathrm{Na}, \mathrm{Ca}$ and $\mathrm{Mg}$ results from samples collected in January, June and December 2013 (Table 1). The January 2013 period covered a consistent recession period (see Fig. 4), while the June 2013 period included a flow event midway through the sampling period. The December 2013 sampling covered a 2 day "snapshot" during a recession period. The valid range of groundwater and ungauged tributary discharges generated by varying the groundwater end-member concentration by \pm 1 standard deviation is shown in brackets after the values generated by the mean groundwater composition in Table 1 .

In January 2013, the selected ions showed similar downstream (i.e. Sayers Bridge to Bunker Hill) percentage increases (62-82\%) during the recession events and cross plots (not shown) indicated that $\mathrm{Na}, \mathrm{Ca}$ and $\mathrm{Mg}$ were showing conservative behaviour relative to $\mathrm{Cl}$. The mass balance analy- 
Table 1. Estimates of groundwater discharge $\left(Q_{\mathrm{gw}}\right)$ and ungauged tributary discharge $\left(Q_{\mathrm{ut}}\right)$ using mass balance analysis and mean measured compositions of groundwater and ungauged tributary flow. The values within the brackets are the range of valid discharges generated by varying the groundwater composition by 1 standard deviation for each ion used in the analysis. $Q_{\text {res }}$ is the residual discharge after accounting for the gauged discharges within the study catchment and the following value in brackets is the ratio of $Q_{\text {res }}$ to the total streamflow measured at Bunker Hill gauging station.

\begin{tabular}{|c|c|c|c|c|c|}
\hline Date & $Q_{\mathrm{gw}} \quad\left(\mathrm{MLd}^{-1}\right)$ & $\left(\mathrm{MLd}^{-1}\right)$ & $Q_{\mathrm{res}}\left(\mathrm{MLd}^{-1}\right)$ & Tracer & Method \\
\hline 21 Jan 2013 & $14.0(4.0-14.0)$ & $2.8(2.8-12.8)$ & $16.8(0.45)$ & $\mathrm{Cl}-\mathrm{Ca}$ & Two end-member \\
\hline 21 Jan 2013 & $12.0(7.0-12.0)$ & $4.8(4.8-9.8)$ & $16.8(0.45)$ & $\mathrm{Cl}-\mathrm{Mg}$ & Two end-member \\
\hline 21 Jan 2013 & $14.8(1.3-14.8)$ & $2.0(2.0-15.5)$ & $16.8(0.45)$ & $\mathrm{Ca}-\mathrm{Mg}$ & Two end-member \\
\hline 21 Jan 2013 & $-(4.4-7.6)$ & $-(9.2-12.4)$ & $16.8(0.45)$ & $\mathrm{Na}-\mathrm{Mg}$ & Two end-member \\
\hline 21 Jan 2013 & $-(10.3)$ & $-(6.5)$ & $16.8(0.45)$ & $\mathrm{Na}-\mathrm{Ca}$ & Two end-member \\
\hline 21-28 Jan 2013 & $13.7(5.3-13.7)$ & $1.8(1.8-10.2)$ & $15.5(0.45)$ & $\mathrm{Cl}$ & One end-member series \\
\hline 21-28 Jan 2013 & $7.1(3.8-12.6)$ & $8.4(2.9-11.7)$ & $15.5(0.45)$ & $\mathrm{Na}$ & One end-member series \\
\hline 21-28 Jan 2013 & $13.7(8.9-13.7)$ & $1.8(1.8-6.6)$ & $15.5(0.45)$ & $\mathrm{Ca}$ & One end-member series \\
\hline 21-28 Jan 2013 & $13.7(7.7-13.7)$ & $1.8(1.8-7.9)$ & $15.5(0.45)$ & $\mathrm{Mg}$ & One end-member series \\
\hline 21-28 Jan 2013 & $4.7(3.3-8.2)$ & $10.8(7.3-12.2)$ & $15.5(0.45)$ & ${ }^{18} \mathrm{O}$ & One end-member series \\
\hline 21-28 Jan 2013 & $8.1(4.6-8.1)$ & $7.5(7.5-10.9)$ & $15.5(0.45)$ & ${ }^{2} \mathrm{H}$ & One end-member series \\
\hline 7 Jun 2013 & $25.2(20.5-25.4)$ & $59.6(59.4-64.3)$ & $84.8(0.43)$ & $\mathrm{Cl}-\mathrm{Na}$ & Two end-member \\
\hline 7 Jun 2013 & $48.8(35.6-53.2)$ & $36.0(31.6-49.2)$ & $84.8(0.43)$ & $\mathrm{Na}-\mathrm{Mg}$ & Two end-member \\
\hline 7 Jun 2013 & $38.2(7.5-38.2)$ & $46.6(46.6-77.3)$ & $84.8(0.43)$ & $\mathrm{Cl}-\mathrm{Ca}$ & Two end-member \\
\hline 7 Jun 2013 & $68.9(36.6-68.9)$ & $15.9(15.9-48.2)$ & $84.8(0.43)$ & $\mathrm{Cl}-\mathrm{Mg}$ & Two end-member \\
\hline 7 Jun 2013 & $9.8(9.8-16.6)$ & $75.0(68.2-75.0)$ & $84.8(0.43)$ & $\mathrm{Na}-\mathrm{Ca}$ & Two end-member \\
\hline 7-11 Jun 2013 & $-(18.8-29.9)$ & $-(17.1-28.2)$ & $47.0(0.41)$ & $\mathrm{Cl}$ & One end-member series \\
\hline 7-11 Jun 2013 & $2.2(1.2-20.5)$ & $44.8(26.5-45.8)$ & $47.0(0.41)$ & $\mathrm{Na}$ & One end-member series \\
\hline 20 Jun 2013 & $14.7(10.0-14.9)$ & $31.0(30.8-35.7)$ & $45.7(0.38)$ & $\mathrm{Cl}-\mathrm{Na}$ & Two end-member \\
\hline 20 Jun 2013 & $42.4(3.8-42.4)$ & $3.3(3.3-34.3)$ & $45.7(0.38)$ & $\mathrm{Na}-\mathrm{Mg}$ & Two end-member \\
\hline 20 Jun 2013 & $-(44.5)$ & $-(1.2)$ & $45.7(0.38)$ & $\mathrm{Cl}-\mathrm{Mg}$ & Two end-member \\
\hline 20 Jun 2013 & $-(0.2-1.0)$ & $-(34.8-35.6)$ & $45.7(0.38)$ & $\mathrm{Cl}-\mathrm{Ca}$ & Two end-member \\
\hline 20 Jun 2013 & $-(15.3-17.9)$ & $-(17.9-20.5)$ & $45.7(0.38)$ & $\mathrm{Na}-\mathrm{Ca}$ & Two end-member \\
\hline 18-20 Jun 2013 & $51.9(31.3-51.9)$ & $0.3(0.3-20.9)$ & $52.2(0.42)$ & $\mathrm{Cl}$ & One end-member series \\
\hline 18-20 Jun 2013 & $-(27.3-36.4)$ & $-(15.8-24.9)$ & $52.2(0.42)$ & $\mathrm{Na}$ & One end-member series \\
\hline 18-20 Jun 2013 & $-(36.9)$ & $-(15.3)$ & $52.2(0.42)$ & $\mathrm{Cl}-\mathrm{Na}$ & Two end-member series \\
\hline 18-20 Jun 2013 & $-(17.3-45.2)$ & $-(7.0-34.9)$ & $52.2(0.42)$ & $\mathrm{Ca}-\mathrm{Mg}$ & Two end-member series \\
\hline 16 Dec 2013 & $5.3(5.3-26.6)$ & $30.6(9.2-30.6)$ & $35.8(0.30)$ & $\mathrm{Na}-\mathrm{Ca}$ & Two end-member \\
\hline 16 Dec 2013 & $17.1(0.2-17.1)$ & $18.7(18.7-35.8)$ & $35.8(0.30)$ & $\mathrm{Cl}-\mathrm{Ca}$ & Two end-member \\
\hline 16 Dec 2013 & $-(16.2-16.6)$ & $-(19.2-19.6)$ & $35.8(0.30)$ & $\mathrm{Na}-\mathrm{Cl}$ & Two end-member \\
\hline 16 Dec 2013 & $-(3.8-12.6)$ & $-(23.2-32.1)$ & $35.8(0.30)$ & $\mathrm{Na}-\mathrm{Mg}$ & Two end-member \\
\hline 16 Dec 2013 & $-(18.0)$ & $-(17.8)$ & $35.8(0.30)$ & $\mathrm{Ca}-\mathrm{Mg}$ & Two end-member \\
\hline 16 Dec 2013 & $-(2.3-33.4)$ & $-(2.4-33.6)$ & $35.8(0.30)$ & $\mathrm{Cl}-\mathrm{Mg}$ & Two end-member \\
\hline
\end{tabular}

sis (Table 1) showed that a range of groundwater discharge and ungauged tributary values was valid, even during summer low flow conditions. This was consistent with field observations that a number of the larger ungauged tributaries were flowing in January 2013, and this was also the case in the June and December 2013 field trips. In June 2013, before and after a flow event, the selected ions showed more variable downstream (i.e. Upper Gellibrand to Bunker Hill) percentage increases (57-124\%). The resulting mass balance analyses again showed a range of contributions from the groundwater discharge and ungauged tributary flow terms (Table 1). A number of combinations of end-members could not return physically realistic estimates (i.e. one discharge term being negative).
Allowing for variation within the groundwater endmember composition demonstrated the uncertainty in the range of valid flux estimates. The mass balance analyses indicated that the ungauged tributary flow term was often significant (consistent with field observations) but difficult to separate from the groundwater discharge term. This was likely due to the similarity in signature between these two end-members. The possibility of the ungauged tributary flow forming a distinctively different physical end-member to regional groundwater discharge (i.e. representing a different store and flow path) is further investigated in Sect. 3.5. 

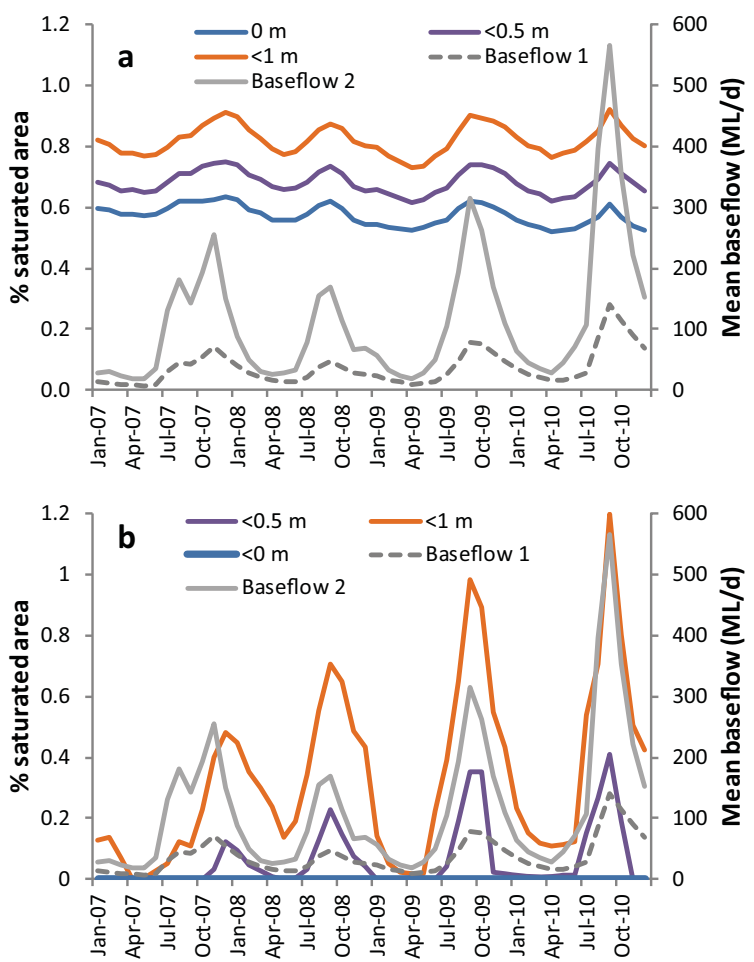

Figure 6. Percentage saturated area (intersection of groundwater surface with land surface) variations over time for the potentiometric (all bores) data set (a) and the water table (33 bores) data set (b) for the catchment area with elevation $<100 \mathrm{~m}$. The position of the water table is shown for three depths $(0,0.5,1.0 \mathrm{~m})$ to allow for uncertainties in the mapping of the depth to water table. The mean daily baseflow for each month is shown for two sets of Eckhardt filter parameter values calculated from the Bunker Hill gauging record. Baseflow 1 uses the low $\mathrm{BFI}_{\max }$ value $(a=0.988$, $\left.\mathrm{BFI}_{\max }=0.20\right)$, while Baseflow 2 uses a higher $\mathrm{BFI}_{\max }$ value $\left(a=0.988, \mathrm{BFI}_{\max }=0.60\right)$.

\subsection{Baseflow-water table dynamics}

The monthly time series of groundwater surface mapping from both the "potentiometric" data set ( 88 bores) and the "water table" data set (33 bores) allows analysis of the dynamics of the relationship between baseflow and groundwater fluctuations and of the spatial distribution of shallow groundwater relative to the sampling of ungauged tributaries. Both sets of groundwater maps showed approximately similar patterns but with the water table surfaces being slightly deeper and with higher standard deviations (see the example in Fig. 5). The maps showed that areas with groundwater $\leq 5 \mathrm{~m}$ from the ground surface were confined to the alluvial plains of the Gellibrand River and one of its major gauged tributaries, Love Creek, and these areas coincided with lower standard deviations in the water table mapping (Fig. 5). The areas of very shallow groundwater $(0 \mathrm{~m},<0.5 \mathrm{~m},<1 \mathrm{~m}$ below the ground surface) were tabulated and plotted for both the "potentiometric" data set and the "water table" data set
(Fig. 6) to identify areas where the groundwater could discharge to the surface or into channels within the uncertainty range of the groundwater mapping. The percentage changes in "saturated area" (i.e. water tables within a specified depth to surface) showed different behaviour between the potentiometric and water table data sets. The potentiometric data set showed areas of artesian head along the valley floors and consistently small seasonal variations with only minor differences between years. For example, the difference between the spring (September-October) peak and autumn (AprilMay) trough was low in absolute terms $(<0.15 \%$ of area $<100 \mathrm{~m}$ in elevation) and relative terms (9-19\% variation between peaks and troughs). In contrast, the water table data set showed that groundwater heads remained below the land surface, but did show much larger variations in absolute area (e.g. $<1.2 \%$ of area for groundwater surfaces within $1 \mathrm{~m}$ of the land surface) and relative size of peaks (e.g. 80-100\%) between years compared to the potentiometric data set. In comparison, the two baseflow time series (using $\mathrm{BFI}_{\max }$ parameter values of 0.2 and 0.6 , see Sect. 3.1) showed large relative variations of $72-95 \%$ between peaks and troughs that were similar to the peak seasonal variation shown by the water table surfaces, but not to the potentiometric surfaces. The peak saturated areas typically coincided with peak estimated baseflow, except for 2007. For both groundwater data sets, the results are generally not consistent, with changes in the saturated area being the dominant driver of peak variations in baseflow, as measured by the Eckhardt filter. In particular, the potentiometric data set shows a far more consistent range in seasonal peaks compared to the digital filter estimated baseflow. While the water table data set does show a similar pattern in seasonal peaks, the water table rarely reaches the land surface. The saturated areas largely coincided (e.g. see Fig. 5) and were restricted to the valley floor of the catchment and with little variation in the location of these areas between dates. The restriction of the saturated areas to the valley floors indicates little regional groundwater discharge into minor tributaries, and this is analysed further in Sect. 3.5.

The analysis of monthly changes in saturated volume and mean monthly Eckhardt baseflow provides further evidence that the regional groundwater discharge is not the major driver of the baseflow time series. The saturated volume changes (at elevations $<100 \mathrm{~m}$ ) for both the potentiometric and water table data sets (Fig. 7) were similar, but with the water table data set showing greater variability between months. The water table variation showed an expected seasonal pattern of peak increases in winter and peak decreases in summer. The baseflow time series showed a lagged response, with peak baseflow occurring in spring. For months in the water table data set with declining saturated volumes (i.e. periods where changes in saturated volume are dominated by discharge), we used a range of specific yield values to convert the total volume change to a volume of discharged water for areas within the $<100 \mathrm{~m}$ mask (Table 2). 
Table 2. Minimum, median and 90th percentile values for the ratio of monthly Eckhardt filter baseflow to "water table" volume changes using a range of specific yields ( $S_{y 1}$ - Wangerrip Group, $S_{y 2}$ - alluvium, $S_{y 3}$ - Heytesbury Group aquitards). Filtered baseflow time series were calculated using an $a$ value of 0.988 and $\mathrm{BFI}_{\max }$ values of 0.2 or 0.6 . Only months with declining volume changes were used in the analysis.

\begin{tabular}{lrrrrrrrr}
\hline & \multicolumn{3}{c}{ Min ratio } & & \multicolumn{2}{c}{ Median ratio } & & \multicolumn{2}{c}{ 90th perc. ratio } \\
\cline { 2 - 3 }$S_{\mathrm{y} 1}, S_{\mathrm{y} 2}, S_{\mathrm{y} 3}$ & $\mathrm{BFI}_{\max }=0.2$ & 0.6 & & 0.2 & 0.6 & & 0.2 & 0.6 \\
\hline $0.1,0.3,0.05$ & 0.41 & 0.89 & & 3.23 & 10.81 & & 27.3 & 57.3 \\
$0.1,0.2,0.05$ & 0.41 & 0.89 & & 3.88 & 12.89 & & 28.4 & 61.7 \\
$0.1,0.1,0.05$ & 0.41 & 0.89 & & 6.77 & 18.06 & & 38.0 & 80.2 \\
$0.15,0.3,0.05$ & 0.27 & 0.59 & & 2.52 & 8.59 & & 15.9 & 33.9 \\
$0.05,0.05,0.05$ & 0.82 & 1.78 & & 11.9 & 32.21 & & 49.8 & 12.5 \\
$0.1,0.1,0.1$ & 0.41 & 0.89 & & 5.96 & 16.11 & & 24.9 & 60.2 \\
$0.2,0.2,0.2$ & 0.21 & 0.45 & & 2.98 & 8.05 & & 12.4 & 30.1 \\
$0.3,0.3,0.3$ & 0.14 & 0.30 & & 1.99 & 5.37 & & 8.3 & 20.1 \\
\hline
\end{tabular}

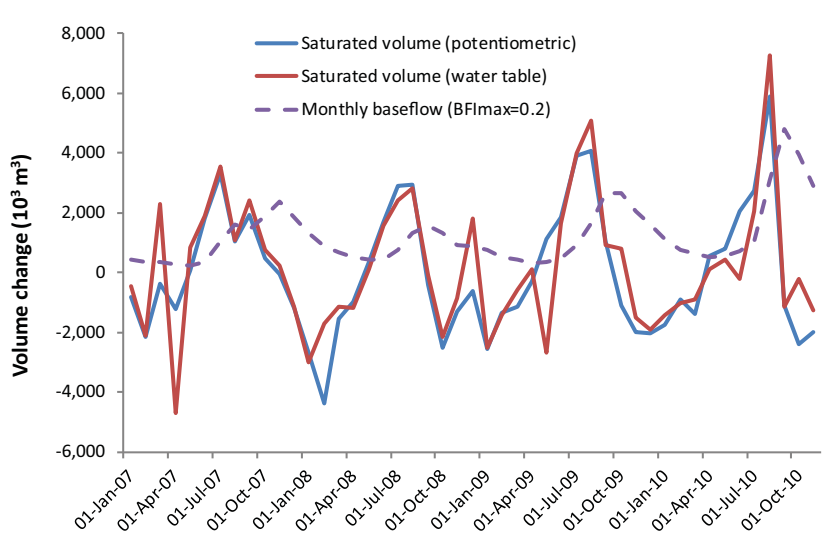

Figure 7. Monthly variations in saturated volumes for the catchment area with elevation $<100 \mathrm{~m}$ for both the potentiometric and water table data sets and for monthly baseflow derived from Eckhardt analysis (using a $\mathrm{BFI}_{\max }$ value of 0.2 ).

There are no pump test data for the catchment, but Atkinson et al. (2014) used a specific yield of 0.1 to estimate recharge for the Eastern View Formation (Wangerrip Group), consistent with the effective porosity of this unit (Love et al., 1993). A hydrogeological modelling study in similar units of the Otway Basin used specific yield values of 0.1 for both aquifers and aquitards in their calibrated model (SKM, 2010). We use a range of realistic but relatively high (Nwankwor et al., 1984) specific yield values from 0.05 to 0.3 for the different geological units within the $<100 \mathrm{~m}$ elevation mask for the groundwater surfaces (see Fig. 1). The estimates of the ratio of monthly baseflow (from the Eckhardt filter) to monthly mapped volume change, shown in Table 2, are generated using the same specific yield values across all geological units and also by varying the values consistently with expected hydrogeological properties (i.e. specific yield of alluvium $>$ Wangerrip Group $>$ Heytesbury Group). We consider that this range of estimates based on these specific yield values provides an upper bound to the groundwater discharge, par- ticularly since any phreatic evapotranspiration flux, which would also account for some of the volume changes, is not considered. For the study period of 2007-2010, only three months showed a ratio of $<1$ between the monthly baseflow time series (generated using $\mathrm{BFI}_{\max }$ values of 0.2 and 0.6 ) and the corresponding monthly change in mapped water table volume (i.e. saturated volume change $>$ baseflow), using the range of specific yield values. The median ratio for both baseflow time series ranged from 2.0 to 32.2 (Table 2), with more realistic (i.e. smaller) specific yield values generating the larger median ratios (i.e. saturated volume change «baseflow) compared to specific yield values considered to represent an upper bound. The late summer to early winter period (January to June, $n=17$ ) had median ratios $10-15 \%$ less than the late winter to early summer period (July to December, $n=20$ ), but both periods had months with very large (>10) ratios. These results indicate that the monthly baseflow fluxes are significantly larger than can be explained by groundwater discharge from the valley regions during most months of the year and requires a significant additional flux of "slow flow" into the river (see also Fig. 9).

\subsection{Relationship between groundwater and tributary chemistry}

The relationship between regional groundwater and ungauged tributary chemistry was examined by grouping subcatchments using the depth to potentiometric groundwater upstream of each sampling point on the ungauged tributaries. The subcatchment areas ranged from 0.4 to $47.4 \mathrm{~km}^{2}$ $\left(\right.$ mean $11.0 \mathrm{~km}^{2}$ ) and the seasonal peak groundwater level in September 2010 was used in the analysis as it was a representative period of seasonal high groundwater levels for the study period. The minimum monthly groundwater depths within the subcatchments ranged from -6 (i.e. above ground surface) to $84 \mathrm{~m}$ below ground surface. Given the uncertainty in the minimum mapped position of the groundwater surface (i.e. see the mapped standard deviation of the 

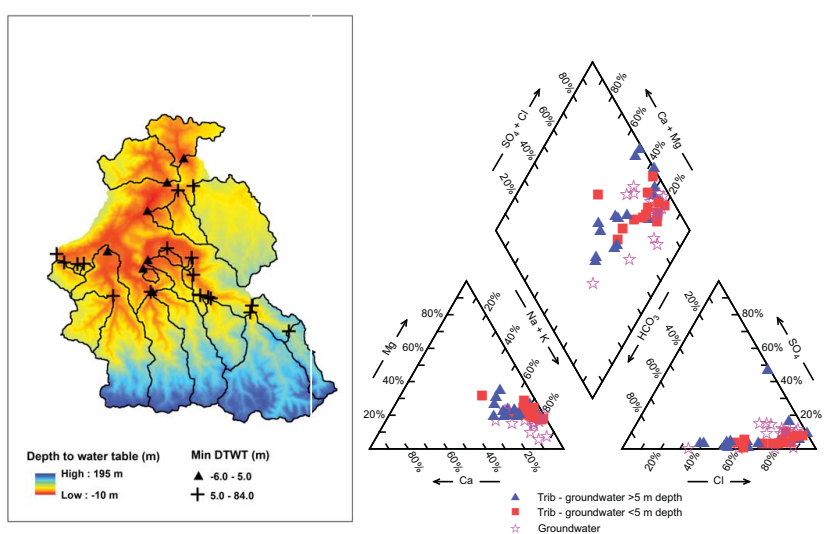

Figure 8. Piper diagram (right) shows tributary samples grouped by the minimum depth to groundwater table in the sub-catchment upstream of the sampling point. Compositions of sampled groundwater bores are also shown. The spatial location and sub-catchment extent are shown superimposed on the potentiometric depth to groundwater map for September 2010.

groundwater position in Fig. 5), the subcatchments were arbitrarily divided between those with groundwater within $5 \mathrm{~m}$ of the land surface anywhere within the sub-catchment (i.e. where groundwater discharge into channels within the subcatchment was possible) and those with deeper groundwater (Fig. 8). There were no significant differences in the tributary compositions in subcatchments with shallow groundwater (i.e. minimum depths $<5 \mathrm{~m}$ from the ground surface) or deep groundwater. These results suggest that seasonal regional groundwater level rises are not likely to drive seasonal increases in ungauged tributary inflow from the upper parts of the catchment. This is consistent with the chemistry of the major tributaries being similar to that of the Gellibrand River flow rather than that of the alluvial groundwater (Fig. 3). Therefore, seasonal increases in ungauged tributary inflow are more likely to be driven by interflow or perched aquifer processes, rather than variations in the regional groundwater. The baseflow filter estimates show large increases in the "slow flow" component of streamflow during winter-spring periods that were not consistent with probable groundwater discharge (Fig. 7). The mass balance calculations indicate that small, ungauged tributaries are a significant contributorto this increase and can be a contributor even during low flow periods.

\section{Discussion}

\subsection{Baseflow estimates}

Digital baseflow filters separate out the "slow flow" component of streamflow. As such, they provide an effective upper bound on possible groundwater discharge to streamflow (Cartwright et al., 2014). This was tested by plotting
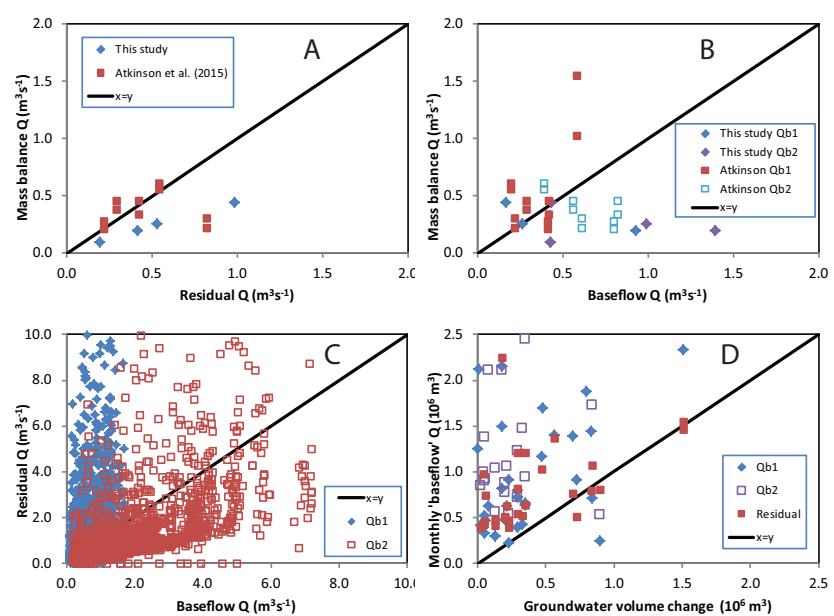

Figure 9. Scatter plots showing various estimates of baseflow and groundwater discharge. (a) Mass balance tracer estimates (from Atkinson et al. (2015) for 2011-2012 and the mid-point of the range shown in Table 1 for 2013) for groundwater discharge against the residual streamflow (Bunker Hill streamflow less upstream gauged streamflow). (b) Mass balance tracer estimates against the Eckhardt filter baseflow estimates $\left(\mathrm{Qb} 1\right.$ uses $a=0.988$ and $\mathrm{BFI}_{\max }=0.2$; Qb2 uses $a=0.988$ and $\mathrm{BFI}_{\max }=0.6$ ). (c) Residual discharge against Eckhardt filter baseflow time series for 2007-2013. (d) Saturated volume changes (using specific yield set $0.15,0.30,0.05$ from Table 2) against residual flow and Eckhardt filter baseflow time series.

scatter plots of baseflow estimates for the Gellibrand River from Eckhardt digital filter analysis, residual streamflow (i.e. Bunker Hill discharge less other gauged tributaries lagged by 1 day - Upper Gellibrand, Lardner Creek, Love Creek) and tracer mass balance analyses (Fig. 9a, b, c) for the 2011-2013 period. The tracer estimates include the range of estimates from Atkinson et al. (2015) for sampling from known dates conducted in 2011-2012 using ${ }^{222} \mathrm{Rn}$ and $\mathrm{Cl}$ mass balance, plus the results from this study for sampling in 2013 using major ions (shown as mid-points of the range for each date shown in Table 1). None of these estimates is directly comparable, as they measure different components of baseflow, but their comparison is informative. The digital filter timeseries estimates baseflow from the entire catchment upstream of Bunker Hill gauging station. The Atkinson et al. (2015) estimates are for the groundwater discharge component of streamflow measured over the alluvial valley reach (approximately two-thirds of the Bunker Hill to Upper Gellibrand reach, see Fig. 1) and use a two end-member mass balance approach (tributary inflow was not considered). The tracer mass balance results from our study are for the groundwater discharge component of baseflow over the Bunker Hill to Upper Gellibrand reach and account for ungauged tributary inflow. For additional comparison, the residual monthly discharge, monthly baseflow and the monthly saturated volume change for months with decreasing volumes were plot- 
ted (Fig. 9d). The saturated volume change was calculated with a realistic specific yield range (set $0.15,0.3,0.05$ in Table 2) that produces a relatively high estimate of groundwater discharge compared to estimates using other specific yield values (see Table 2).

The tracer estimates of groundwater discharge and the residual discharge generally show a consistent relationship (Fig. 9a). The Atkinson et al. (2015) estimates coincided with the residual discharge, except for two outliers from one date sampled on a small rising limb, but neither method separates out in-reach tributary flow from groundwater discharge. The tracer estimates from this study used the residual discharge as an upper bound in their estimation and so show a high correlation and a negative bias with the residual discharge. When the tracer estimates are plotted against two baseflow filter estimates (Fig. 9b, using $a=0.988, \mathrm{BFI}_{\max }=0.2$ and $a=0.988, \mathrm{BFI}_{\max }=0.6$ ) the relationships are poorly correlated and with the tracer estimates both under- and overestimating relative to the baseflow filter estimates. The use of the larger $\mathrm{BFI}_{\max }$ value (0.6), more consistent with the recommendations of Eckhardt (2005), results in the tracer estimates having a more negative bias relative to the baseflow filter estimates. The daily residual discharge is also compared to the baseflow filter estimates over the period 2007-2013 (Fig. 9c). The use of the larger $\mathrm{BFI}_{\max }$ value results in baseflow generally higher than the residual flow (but with considerable scatter) while the lower $\mathrm{BFI}_{\max }$ value results in baseflow generally lower than the residual discharge, particularly at high discharges. Finally, the mapped monthly changes in saturated groundwater volume (see Fig. 7) were plotted against the monthly residual discharge and baseflow filter estimates (using $a=0.988, \mathrm{BFI}_{\max }=0.2$ and 0.6) over the 2007-2010 period (Fig. 9d). The saturated volume changes were typically lower than both the residual discharge and the two baseflow discharges, consistent with the residual and baseflow measures providing an upper bound to groundwater discharge within the study reach. Even the groundwater volume change is more likely to represent an upper bound estimate than an unbiased estimate due to the use of a relatively high specific yield range and not accounting for phreatic evapotranspiration.

Tracer data can be used to calibrate the $\mathrm{BFI}_{\max }$ parameter in the Eckhardt digital filter (Gonzalez et al., 2009) if a suitable end-member signature can be identified. However, in catchments with low salinity alluvial groundwater (i.e. catchments with low groundwater residence time), end-member differentiation can be an issue (Kendall et al., 2001).

The different estimates of baseflow and groundwater discharge emphasise the difficulties in separating and defining these important fluxes, particularly how they vary seasonally. In the context of the catchment used in this study, these variations raise questions of whether the in-reach tributary inflow can be lumped with groundwater discharge (i.e. whether regional groundwater discharge also drives tributary flow) and whether the digital baseflow filter analysis overestimates groundwater discharge during high flow periods. The separation of groundwater discharge from other slow flow pathways (e.g. interflow or perched aquifer discharge driving tributary flow) can be an important distinction for water resource management.

\subsection{Water table dynamics and uncertainties}

The first two hypotheses addressed by this paper involve the ability of monthly groundwater surface dynamics to explain monthly variations in digital filter estimated baseflow. Large increases in baseflow during the high flow season (e.g. winter-spring) could also contain contributions from other slow fluxes (e.g. interflow and perched aquifer discharge contributing to tributary flow, bank storage return). In order to avoid overestimations of groundwater discharge, it is important to independently test the assumption of a single storage (i.e. regional groundwater) driving baseflow.

In terms of the groundwater contribution, we postulated that the main driver of large increases in baseflow would be non-linear increases in the discharge area as groundwater levels rose and intersected more of the land surface. Monthly groundwater surfaces were used to test whether such increases in discharge area are a feasible mechanism. In the case of the Gellibrand catchment, the groundwater data showed that only modest increases in possible discharge area occurred during the seasonal peaks in groundwater levels. The pattern in the magnitude of seasonal peaks of digital filter estimated baseflow was similar to that shown by the water table surfaces but not by the potentiometric surfaces. The limited seasonal variations in the potentiometric surfaces probably reflect the upward gradients observed in bores screened in the Eastern View Formation. The mapped water table surfaces rarely reach the ground surface, but the large seasonal variations in the water table within $1 \mathrm{~m}$ of the ground surface (Fig. 6b) are likely to interact with the drainage system along the valley, particularly within the uncertainty range of the groundwater mapping. Fluctuations in the water table remain a relatively coarse measure and provide only a first-order estimate of possible groundwater discharge patterns. For instance, the mapping does not have the resolution to identify the fine detail of channels and nearstream zones. Stage variations in channels will have local effects on groundwater recharge and discharge that are not captured by the groundwater mapping. Likewise, capillary fringing effects in near-stream zones could lead to rapid increases in the water table with a small rise in water content in the unsaturated zone (Gillham, 1984). Furthermore, the spatial correlation (as defined by the model variogram) may vary with the groundwater level (Lyon et al., 2006; Peterson et al., 2011) and alternative external drift terms to land surface elevation, such as the topographic wetness index, could possibly better represent near-stream spatial heterogeneity.

The groundwater mapping technique also assumes that the groundwater-river interaction is dominated by uncon- 
fined groundwater. Atkinson et al. (2015) found that much of the estimated groundwater discharge (50-90\%) in the study catchment was occurring over a short $5-10 \mathrm{~km}$ reach where the river intersected the outcropping Eastern View Formation, the main regional semi-confined aquifer. It is quite possible that variations in discharge from this regional aquifer may not be adequately represented by changes in the potentiometric groundwater surfaces or the water table. However, temporal changes in the saturated volume of the groundwater, as estimated by groundwater surface mapping, should provide a first-order control on the total amount of groundwater discharge. The digital filter estimates of baseflow were generally significantly larger in most months than could be explained by estimates of groundwater volume change in these periods using specific yield values likely to represent the upper bound of the specific yield range of the different geological units within the catchment. This "excess" baseflow most likely represents interflow and hillslope perched aquifer discharge contributing to streamflow as the catchment drains following the winter-spring wet season.

The generation of the potentiometric surface (using 88 bores) and the water table (using 33 bores) gives an indication of the sensitivity of the use of groundwater surface mapping to the number of data available. The maps generated from the two data sets showed some differences, particularly in the minimum depths to groundwater and the increase in the standard deviation of the water table data set (e.g. see Fig. 5). The increase in the standard deviation of each monthly groundwater surface from the use of fewer bores demonstrates the expected result that confidence in the groundwater mapping analysis will decrease with fewer data points. However, in the case of the Gellibrand catchment, the similar estimates of monthly saturated volume changes from both data sets (Fig. 8) indicated that the relative differences between monthly groundwater surfaces generated by the two data sets were small. This is probably because most monitoring bores in both data sets were located on the valley floors, and so confidence in the interpolated water table surfaces was highest in these areas. These areas are also of most interest in investigating groundwater-river interactions. The effectiveness of groundwater mapping as a water resource assessment tool will depend on the number of monitoring bores within a catchment, but the question of how many monitoring bores are required will be highly dependent on the catchment size and spatial distribution of bores. In this study area, monitoring bores were commonly located in clusters and transects of limited length and these locations were likely determined by ease of access for drilling and the specific aims of past investigations rather than to optimise the spatial distribution of groundwater observations for catchment-wide water table mapping. As a result, the uncertainty of groundwater surface maps would be very catchment specific and difficult to generalise to other locations.

\subsection{End-member-water table dynamics}

The geostatistical mapping of groundwater surfaces in conjunction with terrain analysis allows the testing of endmember assumptions. For example, streamflow from small tributaries during dry periods could be sourced primarily from regional unconfined groundwater or perched aquiferinterflow-type processes. Given the lack of availability of piezometers targeting the latter pathways in most catchments, the capacity to test the possible source of tributary flow provides important information on the suitability of the tributary flow as a separate end-member to flow in the main river. In this context, the results from this study clearly show that much of the small tributary flow in the Gellibrand catchment has a similar chemical signature to the regional groundwater. Nevertheless, most tributaries were sampled from subcatchments with regional groundwater significantly deeper than the land surface. The chemical similarities between the small tributary flow (probably representing interflow) and the regional groundwater was not unexpected given that it is likely that this interflow development is the major contributor to the deeper regional groundwater recharge. The ionic similarities between these end-members illustrate that mass balance techniques will struggle to separate these fluxes with any confidence and that additional, independent data, such as water table mapping, are required to confidently identify the groundwater discharge flux.

\section{Conclusions}

Geostatistical mapping of unconfined groundwater surfaces provides a useful, independent data set for investigating sources of fluxes contributing to baseflow estimated by traditional digital filter and tracer end-member approaches. In particular, the method can provide added confidence in the lower bound of baseflow estimates that best correspond to regional groundwater discharge in both low and high flow periods. Specifically, the groundwater surface data set can be used to identify whether variations in discharge area (i.e. groundwater intersecting the land surface) or saturated volume can explain seasonal variations in baseflow, as estimated using digital filters. This data set is particularly useful in humid, hilly catchments where interflow or perched aquifer discharge is likely to be a significant process and where the different "slow flow" fluxes have similar low salinity chemistry that hinders end-member analysis. Sufficient monitoring bore data to construct water table maps are not available in all catchments and the method is likely to be restricted to catchments where groundwater investigations have resulted in the existence of an adequate bore network. The adequacy of the network will depend on catchment size, the spatial distribution of bores (i.e. uniform versus nonuniform distribution, location relative to the drainage network) and the spatial correlation of the monitored water 
level. However, where adequate monitoring data are available, this method adds significant value to water resource management by making better use of an independent, but often under-utilised, data set that can inform groundwater contributions to streamflow.

\section{The Supplement related to this article is available online at doi:10.5194/hess-19-1599-2015-supplement.}

Author contributions. J. F. Costelloe, A. W. Western and J. J. McDonnell designed the field experiments and analyses. K. Halbert and T. J. Peterson designed and carried out the groundwater mapping, with T. J. Peterson developing the model code for the temporal interpolation of groundwater observations and mapping of groundwater surfaces. J. F. Costelloe carried out most of the data analysis and prepared the manuscript with contributions from all co-authors.

Acknowledgements. This work is funded by the Australian Research Council Discovery Project scheme through project DP120100253. We greatly appreciate the provision of groundwater chemistry data and introduction to the Gellibrand catchment by Alex Atkinson and Ian Cartwright from Monash University. We thank two anonymous reviewers and Ian Cartwright for their insightful and constructive reviews that helped improve this paper.

Edited by: T. Bogaard

\section{References}

Abedini, M. J., Nasseri, M., and Burn, D. H.: The use of a genetic algorithm-based search strategy in geostatistics: application to a set of anisotropic piezometric head data, Comput. Geosci., 41, 136-146, 2012.

Atkinson, A. P., Cartwright, I., Gilfedder, B. S., Cendón, D. I., Unland, N. P., and Hofmann, H.: Using ${ }^{14} \mathrm{C}$ and ${ }^{3} \mathrm{H}$ to understand groundwater flow and recharge in an aquifer window, Hydrol. Earth Syst. Sci., 18, 4951-4964, doi:10.5194/hess-18-49512014, 2014.

Atkinson, A. P., Cartwright, I., Gilfedder, B. S., Hofmann, H., Unland, N. P., Cendón, D. I., and Chisari, R.: A multi-tracer approach to quantifying groundwater inflows to an upland river; assessing the influence of variable groundwater chemistry, Hydrol. Process., 29, 1-12, doi:10.1002/hyp.10122, 2015.

Boezio, M. N. M., Costa, J. F. C. L., and Koppe, J. C.: Kriging with an external drift versus collocated cokriging for water table mapping, Appl. Earth Sci. Transactions of the Institution of Mining \& Metallurgy, Section B, 115, 103-112, 2006.

Bredehoeft, J. D., Papadopulus, S. S., and Cooper Jr., H. H.: Groundwater: the water budget myth in scientific basis of water resource management. National Research Council Geophysics Study Committee, National Academy Press, Washington, DC, 51-57, 1982.
Brutsaert, W.: Long-term groundwater storage trends estimated from streamflow records: Climatic perspective, Water Resour. Res., 44, W02409, doi:10.1029/2007WR006518, 2008.

Cartwright, I., Hofman, H., Sirianos, M. A., Weaver, T. R., and Simmons, C. T.: Geochemical and ${ }^{222} \mathrm{Rn}$ constraints on baseflow to the Murray River, Australia, and timescales for the decay of lowsalinity groundwater lenses, J. Hydrol., 405, 333-343, 2011.

Cartwright, I., Gilfedder, B., and Hofmann, H.: Contrasts between estimates of baseflow help discern multiple sources of water contributing to rivers, Hydrol. Earth Syst. Sci., 18, 15-30, doi:10.5194/hess-18-15-2014, 2014.

Chen, X. and Wang, D.: Evaluating the effect of partial contributing storage on the storage-discharge function from recession analysis, Hydrol. Earth Syst. Sci., 17, 4283-4296, doi:10.5194/hess17-4283-2013, 2013.

Cook, P. G., Favreau, G., Dighton, J. C., and Tickell, S.: Determining natural groundwater influx to a tropical river using radon, chlorofluorocarbons and ionic environmental tracers, J. Hydrol., 277, 74-88, 2003.

Desbarats, A. J., Logan, C. E., Hinton, M., and Sharpe, D. R.: On the kriging of water table elevations using collateral information from a digital elevation model, J. Hydrol., 255, 25-38, 2002.

Eckhardt, K.: How to construct recursive digital filters for baseflow separation, Hydrol. Process., 19, 507-515, 2005.

Eckhardt, K.: A comparison of baseflow indices, which were calculated with seven different baseflow separation methods, J. Hydrol., 352, 168-173, 2008.

Fenicia, F., Savenije, H. H. G., Matgen, P., and Pfister, L.: Is the groundwater reservoir linear? Learning from data in hydrological modelling, Hydrol. Earth Syst. Sci., 10, 139-150, doi:10.5194/hess-10-139-2006, 2006.

Gillham, R. W.: The capillary fringe and its effect on water-table response, J. Hydrol., 67, 307-324, 1984.

Gonzales, A. L., Nonner, J., Heijkers, J., and Uhlenbrook, S.: Comparison of different base flow separation methods in a lowland catchment, Hydrol. Earth Syst. Sci., 13, 2055-2068, doi:10.5194/hess-13-2055-2009, 2009.

Jencso, K. G. and McGlynn, B. L.: Hierarchical controls on runoff generation: Topographically driven hydrologic connectivity, geology and vegetation, Water Resour. Res., 47, W11527, doi:10.1029/2011WR010666, 2011.

Jencso, K. G., McGlynn, B. L., Gooseff, M. N., Wondzell, S. M., Bencala, K. E., and Marshall, L. A.: Hydrologic connectivity between landscapes and streams: Transferring reach- and plot-scale understanding to the catchment scale, Water Resour. Res., 45, W04428, doi:10.1029/2008WR007225, 2009.

Kendall, C., McDonnell, J. J., and Gu, W.: A look inside "black box" hydrograph separation models: a study at the Hydrohill catchment, Hydrol. Process., 15, 1877-1902, 2001.

Leblanc, M., Tweed, S., Van Dijk, A., and Timbal, B.: A review of historic and future hydrological changes in the Murray-Darling Basin, Global Planet. Change, 80-81, 226-246, 2012.

Li, L., Maier, H. R., Partington, D., Lambert, M. F., and Simmons, C. T.: Performance assessment and improvement of recursive digital baseflow filters for catchments with different physical characteristics and hydrological inputs, Environ. Modell. Softw., 54, 39-52, 2014. 
Llamas, M. R. and Martínez-Santos, P.: Intensive groundwater use: Silent revolution and potential source of social conflicts, J. Water Res. Plan. Manag., 131, 337-341, 2005.

Love, A. J., Herczeg, A. L., Armstrong, D., Stadter, F., and Mazor, E.: Groundwater flow regime within the Gambier Embayment of the Otway Basin, Australia: evidence from hydraulics and hydrochemistry, J. Hydrol., 143, 297-338, 1993.

Lyon, S. W., Seibert, J., Lembo, A. J., Walter, M. T., and Steenhuis, T. S.: Geostatistical investigation into the temporal evolution of spatial structure in a shallow water table, Hydrol. Earth Syst. Sci., 10, 113-125, doi:10.5194/hess-10-113-2006, 2006.

McCallum, J. L., Cook, P. G., Brunner, P., and Berhane, D.: Solute dynamics during bank storage flows and implications for chemical base flow separation, Water Resour. Res., 46, W07541, doi:10.1029/2009WR008539, 2010.

McGlynn, B. L. and McDonnell, J. J.: Quantifying the relative contribution of riparian and hillslope zones to catchment runoff, Wat. Resour. Res., 39, 1310, doi:10.1029/2003WR002091, 2003.

Meshgi, A., Schmitter, P., Babovic, V., and Chui, T. F. M.: An empirical method for approximating stream baseflow time series using groundwater table fluctuations, J. Hydrol., 519, 1031-1041, doi:10.1016/j.jhydrol.2014.08.033, 2014.

Nathan, R. J. and McMahon, T. A.: Evaluation of automated techniques for base flow and recession analyses, Water Resour. Res., 26, 1465-1473, 1990.

Nwankwor, G. I., Cherry, J. A., and Gillham, R. W.: A comparative study of specific yield determinations for a shallow sand aquifer, Ground Water, 22, 764-772, 1984.

Ortiz, C. J. and Deutsch, C. V.: Calculation of uncertainty in the variogram, Math. Geol., 34, 169-183, 2002.

Perrin, J., Mascré, C., Pauwels, H., and Ahmed, S.: Solute recycling: An emerging threat to groundwater quality in southern India, J. Hydrol., 398, 144-154, 2011.

Peterson, T. J. and Western, A. W.: Nonlinear time-series modeling of unconfined groundwater head, Water Resour. Res., 50, 83308355, doi:10.1002/2013WR014800, 2014.
Peterson, T. J., Cheng, X., Western, A. W., Siriwardena, L., and Wealands, S. R.: Novel indicator geostatistics for water table mapping that incorporate elevation, land use, stream network and physical constraints to provide probabilistic estimation of heads and fluxes, in: Proceeding of the 19th International Congress on Modelling and Simulation, Perth, Australia, 12-16 December 2011, 3910-3916, 2011.

SKM: Glenelg Hopkins CMA groundwater model - final model development report, Report to the Victorian Department of Sustainability and Environment, available at: https://ensym.dse.vic.gov. au/docs/GlenelgHopkins_TransientModelReport_FINAL.pdf (last access: 5 February 2015), 2010.

SKM: Newlingrook groundwater investigation - Gellibrand River streambed and baseflow assessment, Report to Barwon Water, Geelong, Australia, available at: http://www.barwonwater.vic. gov.au/vdl/A5711327/Newlingrook groundwater investigation Gellibrand River streambed and baseflow assessment (report by SKM consultants).pdf (last access: 21 January 2014), 2012.

Sophocleous, M.: Interactions between groundwater and surface water; the state of the science, Hydrogeol. J., 10, 52-67, 2002.

Tallaksen, L. M.: A review of baseflow recession analysis, J. Hydrol., 165, 349-370, 1995.

van Dijk, A. I., Beck, H. E., Crosbie, R. S., de Jeu, R. A., Liu, Y. Y., Podger, G. M., Timbal, B., and Viney, N. R.: The Millennium Drought in southeast Australia (2001-2009): Natural and human causes and implications for water resources, ecosystems, economy, and society, Water Resour. Res., 49, 1040-1057, doi:10.1002/wrcr.20123, 2013.

Ward, R. C. and Robinson, M.: Principles of Hydrology, 4th Edn., McGraw-Hill, New York, 2000.

Wittenberg, H.: Baseflow recession and recharge as nonlinear storage processes, J. Hydrol., 219, 20-33, 1999.

Wittenberg, H. and Sivapalan, M.: Watershed groundwater balance estimation using stream-flow recession analysis and baseflow separation, Hydrol. Process., 13, 715-726, 1999.

Woessner, W. W.: Stream and fluvial plain ground water interactions: rescaling hydrogeologic thought, Ground Water, 38, 423 429, doi:10.1111/j.1745-6584.2000.tb00228.x, 2000. 